\title{
HUBUNGAN SUDUT INTERINSISAL DENGAN PROFIL JARINGAN LUNAK WAJAH MENURUT ANALISIS HOLDAWAY PADA MAHASISWA FKG USU RAS CAMPURAN PROTO DAN DEUTRO-MELAYU
}

\author{
(CORRELATION BETWEEN INTERINCISAL ANGLE AND SOFT TISSUE FACIAL \\ PROFILE WITH HOLDAWAY ANALYSIS IN MIXED PROTO AND \\ DEUTRO-MALAY RACE)
}

\author{
Nurhayati Harahap, Melisa \\ Departemen Ortodonsia \\ Fakultas Kedokteran Gigi, Universitas Sumatera Utara \\ JL. Alumni No. 2 Kampus USU Medan 20155
}

\begin{abstract}
The incisor inclination plays an important role in establishing facial esthetics especially one third lower face. This study aimed to know the correlation between interincisal angle and soft tissue facial face profile. Cephalometric radiographs of 50 mixed Proto and Deutro-Malay race from USU's dentistry students were evaluated. The following angular measurements were performed on lateral cephalograms: the interincisal angle was obtained from the intersection of the long axis of the upper and lower first incisor, the soft tissue facial profile with Holdaway's analysis were determined as facial angle (N'-Pog' and Frankfurt horizontal) and H angle (N'-Pog'-Ls). Data was analyzed statistically by using Pearson's correlation test. The results showed that mean values of interincisal angle were $120.76^{\circ}$, facial angle $88.60^{\circ}$, and $\mathrm{H}$ angle $15.74^{\circ}$. As conclusion, there was no relationship between the degree of interincisal angle and facial angle $(\mathrm{r}=0.034)$ but there was a moderate relationship between the degree of interincisal angle and $\mathrm{H}$ angle $(\mathrm{r}=0,441)$.
\end{abstract}

Key words: interincisal angle, facial profile, Holdaway analysis, proto-deutro-malay

\begin{abstract}
Abstrak
Inklinasi insisivus mempunyai peranan penting dalam penentuan estetis wajah terutama sepertiga wajah bawah. Penelitian ini bertujuan untuk mengetahui hubungan sudut interinsisal dengan profil jaringan lunak wajah. Pengukuran dilakukan menggunakan radiografi sefalometri pada 50 orang mahasiswa FKG USU ras campuran Proto dan DeutroMelayu. Pengukuran dilakukan pada sefalogram lateral yaitu sudut interinsisal yang dibentuk dari sumbu memanjang gigi insisivus pertama atas dan bawah, profil jaringan lunak wajah menurut analisis Holdaway yaitu sudut fasial (N'-Pog' dan Frankfurt horizontal) dan sudut H(N'-Pog'-Ls). Data dianalisis dengan uji korelasi Pearson's. Hasil penelitian menunjukkan rerata sudut interinsisal sebesar $120,76^{\circ}$, rerata sudut fasial sebesar $88,60^{\circ}$, dan rerata sudut $\mathrm{H}$ sebesar $15,74^{\circ}$. Dapat disimpulkan, bahwa tidak terdapat korelasi antara sudut interinsisal dengan sudut fasial $(r=0,034)$ tetapi terdapat hubungan sedang antara sudut interinsisal dengan sudut $\mathrm{H}(\mathrm{r}=0,441)$.
\end{abstract}

Kata kunci: sudut interinsisal, profil wajah, analisis Holdaway, proto-deutro-melayu

\section{PENDAHULUAN}

Pada dasarnya perawatan ortodonti bertujuan untuk meningkatkan efisiensi fungsional, keseimbangan struktural dan keselarasan estetik yang efisien, oleh Riedel disebut tiga serangkai yaitu "Utility", "Stability", dan "Beauty". Penentuan estetis wajah seseorang sangat dipengaruhi oleh besarnya su- dut interinsisal karena posisi dan inklinasi gigi insisivus akan berpengaruh pada jaringan lunak wajah terutama sepertiga wajah bagian bawah. ${ }^{1}$ Diagnosis dan rencana perawatan memiliki peranan penting di dalam perawatan ortodonti. Prosedur rencana perawatan didasarkan pada pengukuran jaringan keras, dan beberapa penelitian telah menemukan nilai standar untuk jaringan lunak dan jaringan keras. ${ }^{2}$ 
Analisis sefalometri pada profil jaringan lunak telah dilakukan oleh Burstone, Subtelny, dan Holdaway pada tahun 1983. Beberapa referensi titik analisis telah dikemukakan untuk menilai posisi antero-posterior pada bibir atas dan bawah melalui profil lateral, seperti Steiner, Ricketts, Holdaway, Burstone, dan Sushner. Metode pengukuran mereka banyak digunakan oleh ahli ortodontis untuk mengukur posisi bibir dalam diagnosis dan rencana perawatan. ${ }^{3}$ Lokanata menyatakan bahwa analisis Holdaway lebih baik dibandingkan analisis Ricketts, karena analisis Holdaway tidak menggunakan puncak hidung sebagai titik penentu. Rerata hidung masyarakat Indonesia lebih rendah dibanding ras Kaukasoid. Jacobson dan Vlachos menyatakan bahwa analisis Holdaway lebih rinci, jelas dan luas pembahasannya tentang analisis profil jaringan lunak. ${ }^{4}$ Analisis Holdaway melakukan 11 analisis untuk melihat profil jaringan lunak, tetapi pengukuran cukup diukur pada sudut fasial dan sudut $\mathrm{H}$ karena dapat digunakan sebagai penentuan konveksitas jaringan lunak wajah apakah cembung, cekung, atau lurus. ${ }^{5}$

Posisi gigi insisivus merupakan faktor penting dalam rencana perawatan untuk membuat pasien lebih menarik dan memiliki senyum yang seimbang. Profil wajah pasien biasanya dilihat dari inklinasi gigi anterior dan ortodontis harus mengembalikan posisi insisivus untuk mendapatkan keseimbangan wajah ideal. $^{6}$

Menurut penelitian Agha dkk, terdapat korelasi positif antara sudut interinsisal dan sudut konveksitas profil jaringan lunak wajah pada seluruh sampel penelitian. ${ }^{6}$ Arigato menyatakan ada korelasi lemah dengan nilai signifikan yang tidak bermakna dan positif antara sudut interinsisal dengan profil jaringan lunak wajah. ${ }^{7}$ Sedangkan menurut Susilowati, tidak ada hubungan yang bermakna antara sudut interinsisal dengan konveksitas jaringan lunak wajah pada laki-laki dan perempuan suku Bugis dan Makassar. $^{3}$

Penduduk Indonesia sebagian besar terdiri atas ras Proto-Melayu dan Deutro-Melayu. Ras Proto-Melayu terdiri atas suku Batak, Dayak dan Toraja, sedangkan ras Deutro-Melayu terdiri atas suku Aceh (kecuali Gayo dan Alas), Melayu, Minangkabau, Betawi, Sunda, Jawa, Madura, Bali, Makassar, Bugis, dan Menado. ${ }^{89}$ Dewasa ini, penduduk yang merupakan keturunan ras yang sama telah sulit ditemukan karena banyak penduduk yang menikah dengan ras berbeda, seperti ras campuran antara Proto dan Deutro-Melayu.

Beberapa hasil penelitian menunjukkan belum ada hubungan yang signifikan antara sudut interinsisal dengan profil jaringan lunak. Walaupun demikian, beberapa peneliti berpendapat bahwa ada hubungan antara sudut interinsisal dengan profil jaringan lunak wajah. Oleh karena itu, penulis tertarik untuk melakukan penelitian tentang hubungan sudut interinsisal dengan profil jaringan lunak wajah menurut analisis Holdaway pada mahasiswa FKG USU. Penelitian ini dilakukan pada mahasiswa Indonesia FKG USU ras campuran antara Proto dan DeutroMelayu.

\section{BAHAN DAN METODE}

Jenis penelitian ini adalah penelitian deskriptif analitik dengan pendekatan cross sectional. Penelitian ini telah disetujui pelaksanannya oleh Komisi Etik Penelitian Bidang Kesehatan. Penelitian dilakukan di Bagian Ortodonsia Fakultas Kedokteran Gigi USU. Sampel diperoleh dengan cara purposive sampling. Besar sampel ditentukan dengan rumus perhitungan statistik, diperoleh jumlah sampel sebanyak 25 orang, dengan pertimbangan agar parameter populasi lebih akurat dan hasil pengukuran lebih valid maka jumlah sampel yang digunakan adalah 50 orang.

Seluruh sampel dalam penelitian ini harus memenuhi kriteria sebagai berikut: mahasiswa FKG USU ras campuran Proto dengan Deutro-Melayu, usia minimal 18 tahun, belum pernah dirawat ortodonti, relasi rahang Klas I Angle dengan overbite dan overjet normal (2-4 $\mathrm{mm}$ ), gigi permanen lengkap (kecuali molar 3), crowded dan diastema $\leq 2$ $\mathrm{mm}$, kualitas foto sefalometri lateral baik, tidak ada trauma di kepala dan wajah, tidak ada fraktur dan atrisi gigi insisivus, tidak ada kelainan bentuk dan ukuran gigi, tidak ada agenesis dan mesiodens.

Data dikumpulkan dengan cara responden diminta untuk mengisi kuesioner disertai dengan anamnesa, setelah itu dilanjutkan dengan pemeriksaan klinis rongga mulut menggunakan alat tiga serangkai berdasarkan kriteria inklusi dan eksklusi. Apabila memenuhi syarat, maka dilakukan foto sefalometri lateral di Laboratorium Pramita Medan.

Pada sefalogram lateral masing-masing subjek dilakukan penapakan (tracing). Data yang diambil adalah besar sudut interinsisal dan profil jaringan lunak wajah menurut analisis Holdaway. Sudut interinsisal adalah sumbu memanjang dari gigi insisivus pertama atas dan bawah (Gambar 1). Profil jaringan lunak wajah diukur pada sudut fasial dan sudut $\mathrm{H}$. Sudut fasial diperoleh dari perpotongan Frankfurt horizontal dengan garis N'-Pog'. Sudut $\mathrm{H}$ diperoleh dari perpotongan garis Ls-Pog dan garis N'-Pog' (Gambar 2). 


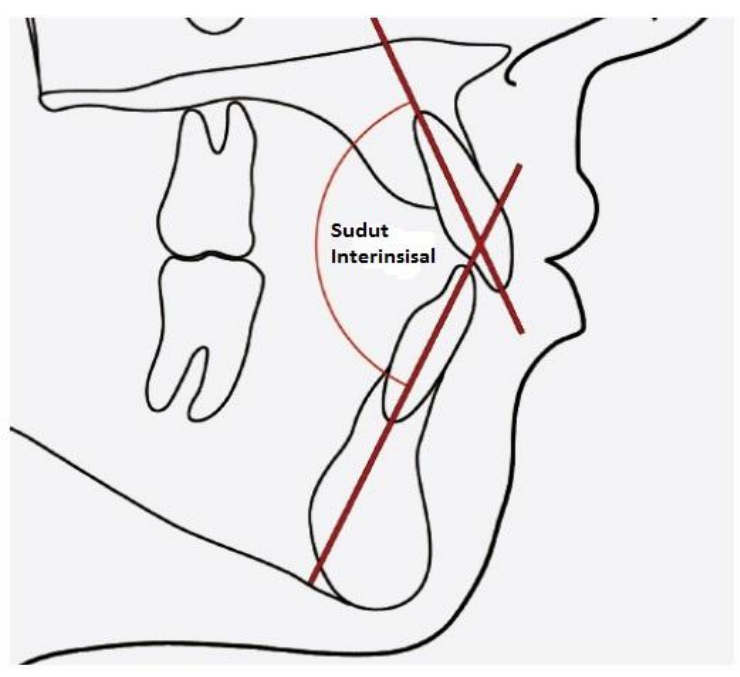

Gambar 1. Sudut interinsisal secara sefalometri

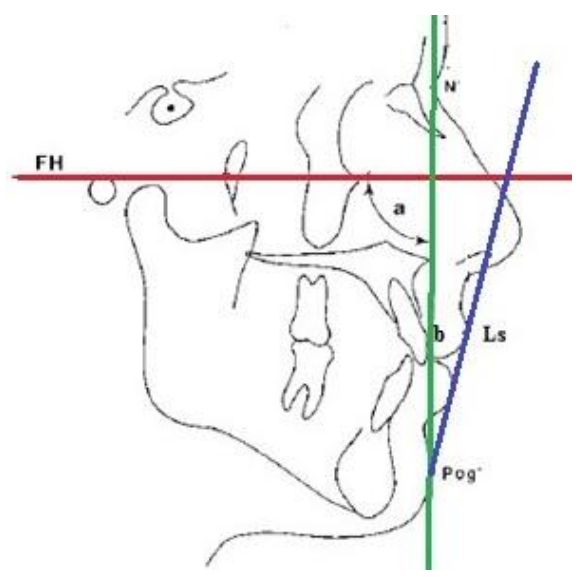

Gambar 2. Sudut fasial (a), sudut H (b), dan bidang Frankfurt Horizontal (FH)

Berdasarkan pengukuran yang telah dilakukan pada sefalogram, selanjutnya dilakukan uji statistik data hasil pengukuran dengan menggunakan program komputer. Sebelumnya dilakukan uji normalitas pada seluruh data hasil pengukuran untuk melihat apakah data tersebut terdistribusi normal yang akan menentukan uji statistik berikutnya. Hasil uji normalitas menunjukkan nilai pengukuran pada 50 sampel penelitian yang telah ditetapkan memiliki distribusi normal $(p>0,05)$ sehingga dapat dilanjutkan dengan uji korelasi Pearson's.

\section{HASIL}

Rerata nilai sudut interinsisal mahasiswa FKG USU ras campuran Proto dan Deutro-Melayu adalah $120,76^{\circ} \pm 10,655$. Rerata nilai sudut fasial mahasiswa FKG USU ras campuran Proto dan DeutroMelayu adalah $88,60^{\circ} \pm 5,163$. Rerata nilai sudut $\mathrm{H}$ mahasiswa FKG USU ras campuran Proto dan Deutro-Melayu adalah $15,74^{\circ} \pm 3,585$ (Tabel 1).
Tabel 1. Rerata nilai sudut interinsisal, sudut fasial, dan sudut $\mathrm{H}$ pada mahasiswa FKG USU ras campuran Proto dan Deutro-Melayu

\begin{tabular}{cccc}
\hline Parameter & N & $\begin{array}{c}\text { Rata- } \\
\text { rata }\end{array}$ & $\begin{array}{c}\text { Simpangan } \\
\text { Baku }\end{array}$ \\
\hline Sudut Interinsisal & 50 & $120,76^{\circ}$ & 10,655 \\
Sudut Fasial & 50 & $88,60^{\circ}$ & 5,163 \\
Sudut H & 50 & $15,74^{\circ}$ & 3,585 \\
\hline
\end{tabular}

Hasil uji korelasi Pearson's yang dilakukan antara sudut interinsisal dengan profil jaringan lunak wajah (sudut fasial) adalah 0,034. Hal ini menunjukkan bahwa kekuatan korelasi sangat lemah dengan nilai signifikan (p) yang tidak bermakna yaitu sebesar 0,812 . Hubungan antara sudut interinsisal dengan profil jaringan lunak wajah (sudut $\mathrm{H}$ ) memiliki nilai signifikan yang bermakna yaitu sebesar 0,001 dengan nilai kekuatan uji korelasi Pearson's (r) sebesar 0,441. Hal ini menunjukkan bahwa hubungan kedua variabel tersebut adalah sedang.

Hasil uji korelasi Pearson's juga memperlihatkan ada hubungan korelasi dalam arah negatif yang berarti sudut interinsisal berbanding terbalik dengan sudut fasial dan sudut H. Jika sudut interinsisal semakin besar maka sudut fasial dan sudut $\mathrm{H}$ akan semakin kecil, begitu juga sebaliknya (Tabel 2).

Tabel 2. Hubungan sudut interinsisal dengan profil jaringan lunak wajah menurut analisis Holdaway pada mahasiswa FKG USU ras campuran antara Proto dan Deutro-Melayu

\begin{tabular}{ccc}
\hline Korelasi & \multicolumn{2}{c}{ Sudut Interinsisal } \\
\cline { 2 - 3 } Pearson's & $\mathrm{p}$ & $\mathrm{r}$ (Pearson's) \\
\hline Sudut Fasial & 0.812 & $-0,034$ \\
Sudut H & 0.001 & $-0,441$ \\
\hline
\end{tabular}

\section{PEMBAHASAN}

Hasil penelitian ini menunjukkan rerata sudut interinsisal mahasiswa ras campuran antara Proto dan Deutro-Melayu FKG USU adalah 120,76 hampir sama dengan hasil penelitian yang telah dilakukan oleh Nurbayati terhadap pasien RSGMP FKG USU dengan rerata sudut interinsisal sebesar $120,20^{\circ} .^{14}$ Selain itu, hasil penelitian Susilowati di Makassar diperoleh rerata sudut interinsisal untuk laki-laki adalah $136,36^{\circ}$ dan $136,03^{\circ}$ untuk perempuan. Rerata sudut interinsisal tersebut lebih besar dibandingkan dengan hasil penelitian ini. Perbedaan ini dapat disebabkan karena populasi penelitian berasal dari suku dan ras yang berbeda. Populasi pada penelitian Susilowati adalah suku Bugis dan Makassar yang termasuk ras DeutroMelayu. $^{3}$ 
Nilai rerata sudut fasial pada penelitian ini adalah $88,60^{\circ}$ dan nilai rerata sudut $\mathrm{H}$ adalah $15,74^{\circ}$. Hasil pengukuran profil jaringan lunak wajah menurut analisis Holdaway dalam penelitian ini berbeda dengan hasil yang didapatkan Rostina dalam penelitiannya pada mahasiswa FKG USU yaitu sudut fasial adalah $91,16^{\circ}$ dan $16,55^{\circ}$ untuk sudut $\mathrm{H}$. Perbedaan ini dapat disebabkan karena subjek pada penelitian tersebut menggunakan ras Deutro-Melayu, sementara pada penelitian ini menggunakan subjek yang berasal dari ras campuran antara Proto dan Deutro-Melayu. ${ }^{8}$

Qadir dkk. dalam penelitiannya mengenai analisis jaringan lunak menggunakan analisis Holdaway mendapatkan rerata sudut fasial sebesar $91,39^{\circ}$ dan rerata sudut $\mathrm{H}$ sebesar $13,13^{\circ}$ pada mahasiswa Irak. ${ }^{11}$ Barakati dkk. dalam penelitiannya mendapatkan rerata sudut fasial sebesar $89,66^{\circ}$ dan rerata sudut $\mathrm{H}$ sebesar $15,16^{\circ}$ pada mahasiswa Saudi Arabia. ${ }^{12}$ Sedangkan Hussein dkk. mendapatkan rerata sudut fasial sebesar $92,17^{\circ}$ dan rerata sudut $\mathrm{H}$ sebesar $14,34^{\circ}$ pada mahasiswa Palestina. ${ }^{13}$ Hasil penelitian tersebut berbeda dengan hasil penelitian ini mungkin karena subjek penelitian berasal dari ras yang berbeda dan jumlah sampel yang berbeda.

Hasil analisis diperoleh adanya hubungan sudut interinsisal dengan sudut fasial tetapi sangat lemah dan tidak signifikan. Selain itu, hasil analisis lain diperoleh adanya hubungan antara sudut interinsisal dengan sudut $\mathrm{H}$ dengan nilai korelasi sedang dan signifikan. Hasil uji korelasi diperoleh dalam arah negatif, artinya semakin besar sudut interinsisal, maka semakin kecil pula sudut fasial dan sudut $\mathrm{H}$, begitu pula sebaliknya.

Hasil ini didukung oleh penelitian yang dilakukan oleh Basciftci dkk. yang melihat perbedaan profil jaringan lunak wajah sebelum dan sesudah dilakukan perawatan ortodonti dengan melakukan retraksi gigi insisivus. Hasil yang diperoleh untuk sudut fasial tidak mengalami perubahan yang signifikan yaitu $87,58^{\circ}$ sebelum perawatan dan $87,83^{\circ}$ sesudah perawatan. Sedangkan hasil yang diperoleh untuk sudut $\mathrm{H}$ mengalami perubahan yaitu $18,25^{\circ}$ sebelum perawatan dan $16,50^{\circ}$ sesudah perawatan. ${ }^{14}$

Sudut $\mathrm{H}$ yang mengalami perubahan setelah dilakukan retraksi insisivus dapat disebabkan karena perubahan letak bibir atas akibat retraksi gigi insisivus sehingga sudut $\mathrm{H}$ menjadi lebih kecil. Hal ini didukung oleh penelitian Waldman yang menyatakan bahwa terdapat korelasi yang signifikan antara perubahan kontur bibir atas dengan retraksi gigi insisivus atas. ${ }^{15}$

Alshakhs melakukan penelitian yang bertujuan untuk melihat perubahan jaringan lunak wajah dengan retraksi gigi insisivus maksila dan mandibula.
Alshakhs menyimpulkan bahwa tidak terdapat perubahan yang signifikan pada letak Pog' sebelum dan sesudah dilakukan retraksi insisivus. ${ }^{16}$ Sudut fasial juga sangat dipengaruhi oleh letak titik Pog' karena menunjukkan maju mundurnya dagu terhadap kepala. ${ }^{3,6}$ Pernyataan tersebut mendukung hasil penelitian ini yang menyatakan bahwa sudut fasial mempunyai hubungan yang sangat lemah dan tidak bermakna dengan sudut interinsisal.

Zen juga melakukan penelitian yang bertujuan untuk melihat adanya hubungan antara jaringan keras dan jaringan lunak menggunakan analisis Ricketts. Zen menyimpulkan bahwa terdapat hubungan antara konveksitas, posisi gigi insisivus bawah terhadap bidang profil, dan posisi bibir menurut analisis Ricketts. ${ }^{1}$ Hasil ini juga didukung oleh Nurbayati yang menyatakan bahwa terdapat hubungan antara profil jaringan lunak wajah dengan sudut interinsisal. ${ }^{10}$

Susilowati juga melakukan penelitian pada suku Bugis dan Makassar dan menemukan bahwa tidak ada hubungan yang bermakna antara besar sudut interinsisal dengan derajat konveksitas jaringan lunak wajah. Perbedaan ini dapat disebabkan karena titik-titik referensi yang digunakan untuk mengukur profil jaringan lunak wajah berbeda. Pada penelitian Susilowati pengukuran profil jaringan lunak wajah yang dipakai adalah analisis Subtelny, titik referensi yang digunakan yaitu N'-Sn-Pog'. Sedangkan penelitian ini menggunakan analisis Holdaway, yang titik referensinya yaitu Ls-Pog'. Selain itu, penelitian Susilowati menggunakan subjek penelitian yang berasal dari suku Bugis dan Makassar sementara pada penelitian ini subjek penelitian berasal dari ras campuran antara Proto dan Deutro-Melayu. ${ }^{3}$

Dapat disimpulkan, bahwa tidak terdapat korelasi antara sudut interinsisal dengan sudut fasial $(r=$ $0,034)$ tetapi terdapat hubungan sedang antara sudut interinsisal dengan sudut $\mathrm{H}(\mathrm{r}=0,441)$.

\section{Daftar Pustaka}

1. Zen Y. Pola hubungan antara konveksitas, posisi gigi insisivus, dan posisi bibir dalam analisa Ricketts. MIKG 2005; 20 (63): 160-8.

2. Ardhana W. Hubungan antara pengukuran inklinasi gigi insisivus sentral secara linier pada model studi dengan pengukuran secara anguler pada sefalogram lateral. MIKG 2004: VI (2): 148-9.

3. Susilowati. Hubungan antara sudut interinsisal dengan derajat konveksitas profil jaringan lunak wajah pada suku Bugis dan Makassar. dentika Dent J 2009; 14(2): 125-8.

4. Lokanata S. Perbandingan lima garis referensi dari posisi horizontal bibir atas dan bibir bawah pada mahasiswa FKG dan FT USU suku Batak. Medan: 
Skripsi. Fakultas Kedokteran Gigi Universitas Sumatera Utara, 2013.

5. Sijabat DN. Hubungan konveksitas skeletal dengan konveksitas jaringan lunak wajah pada pasien remaja suku Batak yang dirawat di klinik ortodonti FKG USU. Medan: Skripsi. Fakultas Kedokteran Gigi Universitas Sumatera Utara, 2011.

6. Agha NF, Ahmad ZM, Dewachi ZB. Correlation of incisors inclination and position with facial profile. Al-Rafidain Dent J 2011; 11(1): 154-60.

7. Arigato. Hubungan sudut interinsisal dengan profil jaringan lunak wajah menurut analisis Ricketts pada mahasiswa suku Batak FKG dan FT USU. Skripsi. Medan: Fakultas Kedokteran Gigi Universitas Sumatera Utara, 2012.

8. Rostina T. Analisis profil jaringan lunak menurut metode Holdaway pada mahasiswa FKG USU suku Deutro Melayu. Tesis. Medan: Fakultas Kedokteran Gigi Universitas Sumatera Utara, 2007.

9. Djoeana H, Nasution FH, Trenggono BS. Antropologi untuk mahasiswa kedokteran gigi. ed 1. Jakarta: Penerbit Universitas Trisakti, 2005: 40-9.

10. Nurbayati S. Hubungan sudut interinsisal terhadap profil jaringan lunak pasien RSGMP FKG USU.
Skripsi. Medan: Fakultas Kedokteran Gigi Universitas Sumatera Utara, 2011.

11. Qadir MYA, Dawoody AD, Agha NF. Evaluation of Holdaway soft tissue analysis for Iraqi adults with class I normal occlusion. Al-Rafidain Dent J 2008; 8(2): 231-37.

12. Barakati SF, Bindayel NA. Holdaway soft tissue cephalometric standards for Saudi adults. King Saud University Dental Science 2012; 3: 27-32.

13. Hussien E, Khateeb SA, Watted N. Evaluation of facial soft tissue parameters for Palestinians using Holaway analysis. The Saudi Dental J 2011; 23: 191-5.

14. Basciftci FA. The influence of extraction treatment on Holdaway soft-tissue measurements. Angle Orthod 2004; 74(2): 167-73.

15. Ramos AL, Sakima MT, Pinto AS, et al. Upper lip changes correlated to maxillary incisor retraction. Angle Orthod 2005; 75 (4): 499-505.

16. Alshakhs ASM. Soft tissue facial profile changes associated with maxillary and mandibular incisors retraction. Tesis. King Saud University, 2007: $17-41$. 